Article

\title{
Corporate Social Performance and Firm Performance: Comparative Study among Developed and Emerging Market Firms
}

\author{
Irene Wei Kiong Ting ${ }^{1}$, Noor Azlinna Azizan ${ }^{2, *}$, Rajesh Kumar Bhaskaran ${ }^{3}{ }^{\mathbb{D}}$ and \\ Sujit K Sukumaran ${ }^{3} \mathbb{D}$ \\ 1 Faculty of Accounting, Ton Duc Thang University, Ho Chi Minh City 758307, Vietnam; \\ irene.ting@tdtu.edu.vn \\ 2 College of Business Administration, Prince Sultan University, Riyadh 12435, Saudi Arabia \\ 3 Department of Finance, Institute of Management Technology, Dubai 345006, UAE; rajesh@imt.ac.ae (R.K.B.); \\ sujit@imt.ac.ae (S.K.S.) \\ * Correspondence: nazizan@psu.edu.sa
}

Received: 5 November 2019; Accepted: 6 December 2019; Published: 18 December 2019

\begin{abstract}
This study examines the impact of firms' environmental, social and governance (ESG) initiatives on financial performance. It also compares the valuation effects of corporate social performance initiatives in developed and emerging market firms. The study was based on ESG ranking scores in the Thomson Reuters database, and the sample comprised 1317 emerging market firms and 3569 developed market firms. In comparison with developed market firms, emerging market firms had higher ESG combined scores, ESG Controversy scores, category scores of resources use, workforce, human rights and corporate social responsibility strategy scores. This study finds that stakeholder initiatives positively impact valuation effects, based on all sample results. Firm-generated controversies may decrease valuation effects in the stock market. Results indicated that ESG initiatives have a significant positive to the firm performance. The presence of independent board members and ownership by investors is a positive determinant for value creation. The adoption of best practice corporate governance principles is an important determinant of the valuation of firms. Firms' propensity to use defence mechanisms decreases valuation effects. Developed market firms received positive valuation effects due to ESG initiatives.
\end{abstract}

Keywords: sustainable initiatives; wealth creation; developed and emerging market firms

\section{Introduction}

Previous research increasingly focused on corporate social relationship, corporate social responsibility and the interface between a firm and society. In terms of corporate social initiatives, developments in the industrial and business world naturally progress, focusing on the improvement of human aspects, environmental preservations and enlightened social consciousness. Advocates of socially responsible actions showcased the benefits that firms receive through improved financial performance [1].

A modern trend indicates that firms are involved in the integration of environmental, social and governance (ESG) objectives in various functional areas. Firms often advertise their corporate social responsibility (CSR) activities and publish formal reports of CSR accomplishments [2].

Several theoretical models on the corporate social performance and corporate financial performance (CSP-CFP) exist. The social impact hypothesis indicates that satisfying the needs and expectations of various stakeholders may increase financial performance [3]. Advocates of the stakeholder theory argued that firms must engage in socially responsible behaviour aimed at energy conservation and 
pollution abatement, which would lead to value creation in the form of improved productivity, corporate reputation and market share. The stakeholder theory assumes much significance to define the appropriate casual relationships between CSP and CFP [4,5]. The trade-off hypothesis indicates that resource allocation aimed at achieving social goals may add to the costs for the firms and prevent profit maximisation. Traditional theorists indicated that CSP and CFP are negatively related [6,7].

In a modern context, firms must focus on profitability, growth potential and social relationships to emerge successful $[8,9]$. A social relationship reflects a firm's diverse commitment to its stakeholders other than profitability and growth potential. It encompasses diverse relationships, such as social, governance and environmental initiatives. The firm's investment in socially responsible behaviour, such as investments directed towards pollution reduction efforts or energy saving technologies, positively impacts financial performance.

The principles of CSR indicated that firms have moral obligations towards society, which are beyond the concept of profit maximisation [10]. Firms create environmental costs through their business operations and are responsible for alleviating these problems [11]. Firms' socially responsible actions can serve business interests and enhance financial performance [12,13].

Social responsibility has great significance and relevance in academia and business management. About $50 \%$ of the global institutional asset base was managed by Principles for Responsible Investment signatories, demonstrating the commitment of financial markets towards the adoption of ESG criteria for investment decisions. Firms incur costs due to ESG initiatives, which are expected to be compensated by the advertising effect of increased brand image, stable revenues from loyal clients, improved employee productivity [14], decreased risk [15] and reduced capital cost [16].

The underlying premise of this research is to explore corporate CSP as a determinant of CFP. It examines the impact of firms' ESG initiatives on financial performance. It also compares the valuation effects of CSP initiatives in developed and emerging market firms.

The remainder of this study proceeds as follows. Section 2 documents related literature. Section 3 reports the data collection and research design of this study. Section 4 discusses the results, whilst Section 5 concludes this paper and presents the limitations of this study and recommendations for future studies.

\section{Literature Review}

\subsection{An Overview of ESG}

ESG helps investors evaluate corporate behaviours and determine the firm's future financial performance. " $\mathrm{E}$ " refers to climate change, pollution, environmental management and water scarcity. "S" refers to employee relation, community involvement, human rights and the involvement of harmful products or services. "G" represents the policies, practices and rules which the firm uses to empower themselves. According to [17], ESG reporting significantly impacts a firm's value. They highlighted that ESG provides insights into corporate management quality and forecast firm performance. ESG information can be identified through rating and reporting. The ESG rating analysis is normally based on the publicly available data reported by the companies and governmental organisations. This study relies on ESG scores as indicators of CSP due to the following reasons. Firstly, ESG describes the company's strategic approach in managing sustainability issues [18]. Secondly, ESG is connected to socially responsible investment, which is a well-recognised investment, and experienced rapid growth among investors [19]. Third, ESG is known as the extra-financial material information of companies in CSR, environmental, sustainability and corporate governance, which are valuable for investors [19].

\subsection{Previous Studies of CSP-CFP}

The compatibility of ESG initiatives with CFP remains a central theme of debate among practitioners and academicians for over five decades. The majority of previous studies reported on the well-founded 
business case for ESG investing. The review of studies from 2008 to 2018 proved that ESG and CFP have mixed results. Investing in ESG activities can improve financial performance [1,2,20-22]. Certain studies reported negative effects $[23,24]$, with ambiguous or contradictory results [25]. These studies focused on developed market firms. By contrast, the current work focuses on examining and comparing the relationship between ESG and CFP in developed and emerging markets. The empirical evidence, with respect to developed markets, may not be applicable to developing markets. Developed and emerging markets significantly differ in terms of their social, cultural and managerial practices [26]. Emerging market firms are characterised by dysfunctional institutions $[27,28]$, barriers due to state control [25], challenging business scenarios and weak corporate governance practices [23].

The early empirical studies of [29] and [30] examined the relationship between a firm's financial performance and socially responsible activities. The CSP-CFP relationship was positively related [11]. One of the major extensive studies on CSP-CFP was conducted by [31] who performed a compendium of 95 studies. Notable studies [3,32-34] analysed the CSP-CFP relationship. The CSR literature focused on the direction of the causality between the firm's financial and social performance. CSP is the predictor of a firm's financial performance in 109 out of 127 studies [35]. In [36], through a meta-analysis of 33,878 samples from the previous 52 studies, the significant and positive relationship between CSP and CFP was confirmed.

For four decades, research on the role and responsibilities of business focused on the business case for CSR [37]. CSP is the outcome of implementing CSR activities, which was related to the firm's relationships with stakeholders [38,39].

The extant literature on CSP focused on the relationship between three key factors, namely, the level of corporate sustainability performance, corporate financial performance and the level/quality of corporate sustainability disclosure [40].

CSP and financial performance are negatively related on the account of costly CSP investments [41]. No adequate theoretical support establishes that CSP and financial performance are directly related [42]. A significant association between CSP and financial performance is not supported [33,41,43,44]. Several studies indicated that CSP was positively related to financial performance [45-47]. The benefits from investing in CSP exceeded costs [4].

Researchers used various sources of CSR data, which were derived from governmental reports, surveys and dimensional CSR measures, such as emissions reduction, charitable donations and environmental indexes. Important aggregate measures used by researchers include Fortune ratings and Kinder, Lyndenberg and Domini (KLD) Research and Analytics. A study by [31] indicated that the most commonly used control variables are firm size, market risk and the industry effects. R\&D spending is expected to positively influence firms' productivity and advertisement expenditure, which is a proxy for product differentiation and entry barriers [44]. The main criteria for measuring financial performance varied from market returns or variables that reflect operating and market performance [35,43].

Social relations offer many advantages for a firm, such as the retention of human resources, customer retention, productivity improvements with environmental management, improvements in local community relationships and attraction of social and ethical investors [48-51]. A positive relationship between social and economic performance is the result of firms' strong ability to manage the expectations of their social context of reference $[36,46]$.

Callan and Thomas [52] documented the positive CSP-CFP performance. The study by [53] based on the replicative study of [46] indicated that CSP may not positively influence CFP. Busch and Friede [54] demonstrated a highly significant, positive and bilateral CSP-CFP relationship. Shin, Moon [55] found that regulative characteristics, such as freedom of competition and political stability, can positively moderate the CSP-CFP relationship. Okamoto [56] analysed the CSP-CFP relationship in Japan using artificial neural networks, indicating that social performance positively affects financial performance. The stronger a firm's involvement in CSR activities, the higher the economic and financial value for firms [57]. 
The study on the relationship between CSP and CFP yielded contradictory results over the last four decades [58]. CSP and CFP are positively, negatively or insignificantly correlated, with various causal directions. Most studies found that CSP and CFP are positively related, as supported by meta-analysis [32,36]. Studies also documented the negative impact of CSR-related activities and behaviours. These studies indicated that CSR practices can generate unnecessary costs which negated competitive advantages [59,60]. The KPMG survey revealed that only half of the companies in 2006 disclosed their social and environmental impacts in sustainability or CSR reports, rising to over $80 \%$ in 2008 [61].

The empirical investigation of the CSP-CFP link requires reorientation to understand its specific dimensions $[31,59,62]$. Numerous studies also tested the mediating mechanism and moderating conditions in CSP-CFP $[4,36]$. They also examined the moderating effects of factors such as R\&D investments [44] and the firm's intangible resources, such as innovation, human capital, reputation and culture [63].

Emerging studies focused on investigating the impact of specific tools and practices on the concept of CSR as a new governance model within the framework of stakeholder relationships which are beyond mere legal compliance [64]. Studies focused on CSR-related natural environmental drivers. The adoption of stringent environmental standards may generate a competitive advantage on the account of the differential potential of green production processes $[48,65]$. Environmental initiatives such as pollution reduction may lead to productivity gains and cost reductions through lowering the consumption of materials, energy and services $[48,66]$. Environmental initiatives can also improve firms' accessibility of sources of funds in the capital market $[15,67,68]$. Environmental-related pollution initiatives can improve the operational and financial performance of firms $[67,69,70]$. Reduced environmental performance decreases firms' financial performance and increases cost of capital [71,72] investigated the factors which drive high levels of corporate sustainability performance (CSP), as proxied by membership of the Dow Jones Sustainability World Index. Using a stakeholder framework, the study found that leading CSP firms are significantly larger and have higher levels of growth and higher return on equity than their counterparts.

Two streams of literature examined the relationship between corporate governance practices and firm performance. One stream focused on the particular aspects of governance, such as board composition, ownership structure, executive compensation and disclosure. The other strand of literature combines the various attributes for the construction of indices of corporate governance quality and examines their relationship in terms of performance.

Weak governance firms receives lower equity returns, worse operating performance and lower firm value in comparison with high governance firms [73]. The beneficial effect of mutual monitoring on firm value was more pronounced for firms with weak corporate governance than those with strong corporate governance [74]. The announcements of reforms which involve board structure may lead to greater wealth effects for larger firms than for smaller firms [75]. A robust and positive association between improvements in shareholder rights ( $G$ index) and abnormal share returns was established via Granger causality tests [73]. Firm characteristics, such as high institutional holdings, low insider holdings and high sales growth, are positively correlated with high governance quality [76]. Firm performance is positively related to stock ownership of board members [77].

Social sustainability involves the identification and management of business impact on people. The most critical determinant of social sustainability was the quality of a firm's relationship and engagement with stakeholders. Employees, workers, customers and local communities are pivotal elements of firm sustainability. The social license to operate a business depends on social sustainability efforts.

CSR may contribute towards improved labour relations, thus increasing employee retention rates and decreasing labour costs [78]. Providing executives with direct incentives for CSR effectively increases firm social performance [79]. Well-governed firms are likely to offer CSR contingent compensation, which may increase the firms' corporate social standing [14]. The study on a value 
weighted portfolio based on the Forbes list of "100 best CSR companies in the world" documented the positive stock market performance and found that companies with good social performance are more likely to have positive earnings than firms with bad social performance [80]. Firms generally have a favourable orientation towards CSR, and the benefits of this strategy include the development and improvement of the firms' reputation [81].

\section{Data and Methodology}

\subsection{Source of Data}

A large dataset from the Thomson Reuters database was gathered to examine the designed hypotheses. The initial sample comprised 7000 companies from 2014 to 2018. Data on ESG ranking scores were required. The sample size was truncated due to missing values of various variables. The final sample comprised 4886 companies. The study divided the sample into emerging and developed market firms at 1317 and 3569, respectively. The emerging market sample firms were from countries such as Argentina (12), Brazil (76), Chile (21), China (217), South Korea (80), Malaysia (54), Indonesia (31), Thailand (38), India (101) and UAE (10). Developed countries are clustered over 20 countries, mostly from the USA (1665), UK (360), Japan (349), Canada (237) and Australia (277).

\subsection{CSP Data Using ESG Scores}

The ESG score reflects firms' fulfilment of environmental, social and governance aspects. Thomson Reuters' ESG scores aim to measure a firm's relative ESG performance based on company-reported data. Two overall ESG scores exist. Following [82], the Thomson Reuters ESG Score measures the company's ESG performance based on available data. The ESG Combined score was discounted for significant ESG controversies, which may impact the firms in the sample data. The ESG Score with ESG controversies provided a comprehensive evaluation on the firm's sustainability impact and conduct. The data was based on approximately 400 company-level ESG measures that were categorised into 10 categories [83]. The category scores were combined into three pillar scores, namely, environmental, social and corporate governance. The governance pillar was used to replace the economic pillar because the increment concern of the governance issue among corporate executives, investors, consumers and the general public led to widespread corporate sustainability initiatives [79].

Based on [84], the ESG score comprised 178 critical measures that reflected the environmental, social and governance elements. A total of 23 controversy measures were included in the ESG Controversies category. The controversy issues include anti-competition, business ethics issues, intellectual properties, public health, tax fraud, child labour, consumer controversies, shareholder issues and workforce issues. Tables 1 and 2 show the pillar and category scores of ESG.

Table 1. Pillar scores.

\begin{tabular}{cc}
\hline Pillar & Major Components \\
\hline Environmental & Resource Use, Emissions, Innovation \\
Social & Workforce, Human Rights, Community, Product Responsibility \\
Governance & Management, Shareholders, CSR Strategy \\
\hline Source: &
\end{tabular}

\subsection{Variables Measurement}

Independent variables: ESG initiatives (ESG) were represented by ESG Score; ESG Combined Score; the pillars of ESG, namely, environmental, governance and social; and the 10 category scores. The ESG and ESG Combined Scores were estimated by averaging the values for the past five years. The pillar scores were also based on the average values for the last five years. The Environmental Score was estimated by adding the average five-year scores of Resource Use, Emissions and Innovations. The Governance Score was estimated by adding the average five-year scores of Management, 
Shareholders and CSR Strategy. The Social Score was estimated by adding the average five-year scores of the workforce, human rights, community and product responsibility. The average five-year component category scores of the three pillars were also estimated to examine its impact on the valuation of firms. The valuation effects of ESG controversies were also examined by the study.

Table 2. Category Scores.

\begin{tabular}{cc}
\hline Scores & \multicolumn{1}{c}{ Measurement } \\
\hline $\begin{array}{c}\text { ESG Resource Use Score } \\
\text { (RS) }\end{array}$ & $\begin{array}{c}\text { Resource Use Score highlights a firm's performance and capacity to reduce the } \\
\text { use of materials, energy or water and to find eco-efficient solutions by improving } \\
\text { supply chain management }\end{array}$ \\
\hline ESG Emissions Score (ES) & $\begin{array}{c}\text { The Emission Reduction Score reflects the firm's commitment and effectiveness in } \\
\text { reducing environmental emission in the production and operational processes. }\end{array}$ \\
\hline ESG Innovation Score (IS) & $\begin{array}{l}\text { The Innovation Score reflects a company's capacity to reduce the environmental } \\
\text { costs and aims to create new market opportunities through new environmental } \\
\text { technologies and processes or eco-designed products. }\end{array}$ \\
\hline
\end{tabular}

ESG Workforce Score (WS)

The Work Score measures a company's effectiveness towards job satisfaction, healthy and safe workplaces, maintaining the diversity and equal opportunities and development opportunities for its workforce.

\begin{tabular}{cc}
$\begin{array}{c}\text { ESG Human Rights Score } \\
\text { (HS) }\end{array}$ & $\begin{array}{r}\text { The Human Rights Score measures a company's effectiveness towards respecting } \\
\text { fundamental human rights conventions. }\end{array}$ \\
\hline $\begin{array}{c}\text { ESG Community Score } \\
\text { (CS) }\end{array}$ & $\begin{array}{r}\text { The Community Score measures a company's commitment towards being a good } \\
\text { citizen, protecting public health and respecting business ethics }\end{array}$ \\
\hline $\begin{array}{c}\text { ESG Product } \\
\text { Responsibility Score (PS) }\end{array}$ & $\begin{array}{r}\text { The Product Responsibility Score reflects a company's capacity to produce quality } \\
\text { goods and services integrating the customer's health and safety, integrity and } \\
\text { data privacy. }\end{array}$ \\
\hline $\begin{array}{c}\text { ESG Management Score } \\
\text { (MS) }\end{array}$ & $\begin{array}{r}\text { The Management Score measures a company's commitment and effectiveness } \\
\text { towards following the best corporate governance principles. }\end{array}$ \\
\hline $\begin{array}{c}\text { ESG Shareholder Score } \\
\text { (SS) }\end{array}$ & $\begin{array}{r}\text { The Shareholder Score measures a firm's effectiveness towards the equal } \\
\text { treatment of shareholders and the use of anti-takeover devices }\end{array}$ \\
\hline $\begin{array}{r}\text { ESG CSR Strategy (CS) } \\
\text { The CSR Strategy Score reflects a company's practices to communicate, in which } \\
\text { it integrates the economic (financial), social and environmental dimensions into } \\
\text { its day-to-day decision-making processes. }\end{array}$ \\
\hline
\end{tabular}

Source: Thomson Reuters Eikon Thomson Reuters ESG Scores May 2018.

Dependent variables: Tobin $Q$ was an appropriate measure for analysing the valuation effects of the observable and unobservable aspects of the relationship between firm and stakeholders. Tobin $Q$ was estimated based on the market value and book value of assets. The market value of assets was estimated as the book value of assets plus the market value of common stocks less the sum of the book value of common stock [85]. The return on equity (ROE) reflects the operating performance measurement in terms of profitability [86]. The price-to-earnings ratio $(\mathrm{P} / \mathrm{E})$ was another valuation measure that represents the earning potential of the firm. The PE ratio is a financial measure which reflects the value market attributes to every unit of earnings of the firm [87].

Control variables: This study used the financial characteristics of firms and governance variables as the control variables. The control variables included were dividend yield, leverage measure of debt to equity (D/E) and debt to total assets, sales growth, R\&D intensity, capex intensity, advertisement intensity, size measured by log of total assets and revenues. The five-year beta value represents the systematic risk. The governance variables included in the model were the percentage of independent board members in the board, strategic investors in the ownership and total shares held by all investors. The ownership variables were also included as control variables in the model.

Dummy variables: Two dummy variables were included in the study, namely, developed nation and emerging market. For the dummy developed nation, one point would be awarded if the firm 
was centred in developed markets; otherwise zero. By contrast, the dummy emerging market is equal to 1 if the firm was centred in emerging markets; otherwise zero. Table 3 summarises the variables' measurements.

Table 3. Variable measurements.

\begin{tabular}{|c|c|}
\hline CSR Variables and Pillar Scores & Measurements \\
\hline ESG_Score (ESG Score) & Latest five-year average \\
\hline ESG_COMSCORE (ESG Combined Score) & Latest five-year average \\
\hline ENV (Environmental Score) & $\begin{array}{c}\text { Adding up the five-year average score of resource use, } \\
\text { emissions and innovations }\end{array}$ \\
\hline SOCIAL (Social score) & $\begin{array}{l}\text { Adding up the average five-year scores of workforces, } \\
\text { human rights, community, product responsibility }\end{array}$ \\
\hline GOVER (Governance score) & $\begin{array}{l}\text { Adding the average five-year scores of management, } \\
\text { shareholders and CSR strategy. }\end{array}$ \\
\hline \multicolumn{2}{|l|}{ Category scores } \\
\hline $\begin{array}{l}\text { RESOURCE, EMMI INNOV } \\
\text { (Environmental Components) }\end{array}$ & \\
\hline $\begin{array}{l}\text { WORK, HUMAN, COMMU, PRODUCT } \\
\text { (Societal Components) }\end{array}$ & Five-year average values for each category \\
\hline MGMT, SHARE, CSR & \\
\hline $\begin{array}{l}\text { (Governance Components) } \\
\text { ESG_CONT (Controversy score) }\end{array}$ & Five-year average score \\
\hline \multicolumn{2}{|l|}{ Performance Variables } \\
\hline Tobin Q & $\begin{array}{c}\text { Market value of assets (total book value of assets minus book } \\
\text { value of equity plus market value of equity)/book value of assets } \\
\text { (five-year average values) }\end{array}$ \\
\hline ROE & Return on equity (five-year average) \\
\hline $\mathrm{P} / \mathrm{E}$ & Price-to-earnings ratio (five-year average) \\
\hline Firm characteristics & (Five-year average values) \\
\hline SIZE_TA (Firm size LogTA) & Log of book value of total assets \\
\hline Age & Log of number of years since the listing of stock \\
\hline Leverage (DEBT_EQUI; DEBTA) & $\begin{array}{l}\text { Book value of debt divided by book value of equity/book value } \\
\text { of debt to total assets }\end{array}$ \\
\hline CAPEX (Capex Intensity) & Capital expenditure/total assets \\
\hline RD (RD Intensity) & R\&D expenses/sales \\
\hline ADV (Advt Intensity) & Advertisement expenses/sales \\
\hline SG (Sales Growth) & Sales in year $\mathrm{t}$ divided by sales in year $\mathrm{t}-1$ (average 5 -year period) \\
\hline BETA (Five-year beta) & Measure of systematic risk \\
\hline DIVD (Dividend yield) & Dividend/market price \\
\hline $\begin{array}{c}\text { MGMT_EFF } \\
\text { (Management Efficiency) }\end{array}$ & Five-year average sales/total asset turnover \\
\hline \multicolumn{2}{|l|}{ Governance Variables } \\
\hline $\begin{array}{l}\text { IND_BOARD (Independent directors in } \\
\text { board) }\end{array}$ & $\begin{array}{c}\text { Number of independent directors/total number of the board of } \\
\text { directors }\end{array}$ \\
\hline $\begin{array}{l}\text { SHARE_INVESTOR Ownership of } \\
\text { shareholders }\end{array}$ & Ownership percentage of shares held by all investors \\
\hline SHARE_STRAT (Institutional Ownership & Percentage share held by strategic investors \\
\hline \multicolumn{2}{|l|}{ Dummy Variables } \\
\hline Dummy Developed nation & Equal to 1 if firm is headquartered in developed market \\
\hline Dummy Emerging Market & Equal to 1 if firm is headquartered in emerging market \\
\hline
\end{tabular}




\subsection{Model Construction}

The multivariate analyses were performed on the following regression model to assess the association between CSP and CFP. The regression model for the study was expressed as

$$
\mathrm{CFP}_{\mathrm{it}}=\mathrm{f}\left(\mathrm{CSP}_{\mathrm{it}-1}\right), \mathrm{X}_{\mathrm{it}}
$$

where $\mathrm{CFP}_{\mathrm{i}}$ is the measure of the firm's financial performance and $\mathrm{CSP}_{\mathrm{i}}$ is the measure of the firm's socially responsible performance. $X_{i t}$ is a vector of control variables which includes the firm's financial characteristics. CFPi is represented by the variables of Tobin's $Q, R O E$ and price-to-earnings ratio $(\mathrm{P} / \mathrm{E})$. $X_{i t}$ represents the control variables, such as advertisement intensity [88], size [89], R\&D [90], beta [91], age [92], capex intensity [93], debt equity ratio [94], debt to total assets [95], dividend yield [96], sales growth [97] and management efficiency ratio [98]. The other moderating variables include a set of variables, such as the percentage of independent board members of the total investor share and investment share of strategic investors. The values for all variables were for the latest five-year period (2014-2018).

\section{Findings and Analysis}

\subsection{Descriptive Statistics}

Table 4 reports the summary statistics, which are given for the ESG and performance variables for emerging and developed market firms. The ESG score measures the company's overall ESG performance. The ESG combined score was discounted for significant ESG controversies. Generally, emerging firms have higher mean and median ESG and ESG combined scores in comparison with developed market firms. In terms of performance variables, emerging market firms have a higher mean and median ROE than developed market firms. The mean and median Tobin $Q$ values were higher for the firms from developed markets than those in emerging market firms. The mean P/E ratio was higher for the emerging market firms, whereas the median $\mathrm{P} / \mathrm{E}$ ratio was higher for the developed market firms.

\subsection{Test of Differences}

Table 5 analyses the mean differences of ESG scores, its pillars and the category scores of emerging and developed market firms. The mean ESG combined scores were higher for emerging market firms than developed market firms with significance $(t=4.22$ with $10 \%$ significance). The mean ESG Controversy scores were higher for emerging market firms than developed market firms with the significance at $10 \%$. The resource score, which measures the effectiveness of supply chain management, was higher for emerging market firms than developed market firms ( $t=2.87$ with $10 \%$ significance). The workforce score, which measures the company's effectiveness towards job satisfaction, healthy and safe workplaces and development opportunities, was higher for emerging market firms than developed market firms. Similarly, in comparison with developed market firms, human rights and community scores were lower for emerging market firms. The CSR strategy scores were higher for emerging market firms than developed market firms. 
Table 4. Summary statistics of environmental, social and governance (ESG) initiatives and financial performance of emerging and developed country firms.

\begin{tabular}{|c|c|c|c|c|c|c|c|c|c|c|}
\hline & \multicolumn{2}{|c|}{ ESG Combined Score } & \multicolumn{2}{|c|}{ ESG Score } & \multicolumn{2}{|c|}{ ROE } & \multicolumn{2}{|c|}{ Tobin's Q } & \multicolumn{2}{|c|}{$\mathrm{P} / \mathrm{E}$} \\
\hline & Emerging & Developed & Emerging & Developed & Emerging & Developed & Emerging & Developed & Emerging & Developed \\
\hline Mean & 50.40 & 48.74 & 54.33 & 53.76 & 13.51 & 11.15 & 2.09 & 2.49 & 31.37 & 30.16 \\
\hline Median & 48.65 & 47.23 & 53.18 & 51.72 & 11.95 & 10.71 & 1.38 & 1.79 & 15.85 & 18.48 \\
\hline $\begin{array}{l}\text { Standard } \\
\text { Deviation }\end{array}$ & 12.53 & 11.34 & 13.55 & 13.77 & 24.68 & 56.61 & 2.04 & 2.75 & 112.31 & 87.93 \\
\hline $\begin{array}{l}\text { Sample } \\
\text { Variance }\end{array}$ & 156.93 & 128.65 & 183.53 & 189.56 & 609.27 & 3204.64 & 4.17 & 7.56 & $12,613.19$ & 7731.54 \\
\hline Kurtosis & -0.42 & -0.04 & -0.65 & -0.62 & 88.93 & 397.67 & 30.75 & 211.74 & 231.84 & 710.91 \\
\hline Skewness & 0.35 & 0.55 & 0.28 & 0.47 & -0.73 & 5.07 & 4.46 & 10.40 & 14.36 & 21.88 \\
\hline Range & 74.42 & 73.55 & 72.88 & 69.94 & 693.72 & 2972.53 & 25.99 & 74.53 & 2101.66 & 3457.14 \\
\hline Minimum & 15.43 & 16.88 & 20.25 & 23.62 & -382.49 & -1154.80 & 0.49 & 0.11 & 0.00 & 0.00 \\
\hline Maximum & 89.85 & 90.43 & 93.13 & 93.56 & 311.23 & 1817.73 & 26.48 & 74.64 & 2101.66 & 3457.14 \\
\hline Count & 1317 & 3569 & 1317 & 3569 & 1254 & 3377 & 1246 & 3446 & 1317 & 3569 \\
\hline
\end{tabular}


Table 5. ESG score comparison: mean characteristics.

\begin{tabular}{cccc}
\hline ESG, Pillars and Category Scores & Emerging & Developed & t-stats \\
\hline ESG Combined Score & 50.40 & 48.74 & $4.22 *$ \\
ESG Score & 54.33 & 53.76 & 1.28 \\
ESG Controversy Score & 52.20 & 49.44 & $6.70 *$ \\
Environmental Pillar Score & 54.42 & 53.39 & 1.64 \\
Social Pillar Score & 54.58 & 54.07 & 0.88 \\
Governance Score & 53.93 & 53.82 & 0.19 \\
Resource use Score & 55.85 & 53.72 & $2.87 *$ \\
Emission Score & 54.93 & 53.88 & 1.32 \\
Environment Innovation Score & 52.42 & 52.53 & -0.15 \\
Workforce Score & 59.62 & 53.60 & $8.02 *$ \\
Human Rights Score & 54.52 & 52.65 & $2.44 *$ \\
Community Score & 46.01 & 56.08 & $-11.69 *$ \\
Product Responsibility Score & 52.90 & 53.76 & -1.05 \\
Management Score & 54.01 & 54.83 & -1.01 \\
Shareholder Score & 52.99 & 52.18 & 1.00 \\
CSR Strategy Score & 55.08 & 52.15 & $3.74 *$ \\
\hline
\end{tabular}

Note: * indicate that the estimated coefficient is significantly different from zero at the $10 \%$ level.

Figure 1 compares the ESG score between emerging and developed markets. Generally, in comparison with developed markets, emerging markets have a higher ESG score, and the ESG from three pillars and category scores, except for the environment innovation score, community score, product responsibility score and management score.

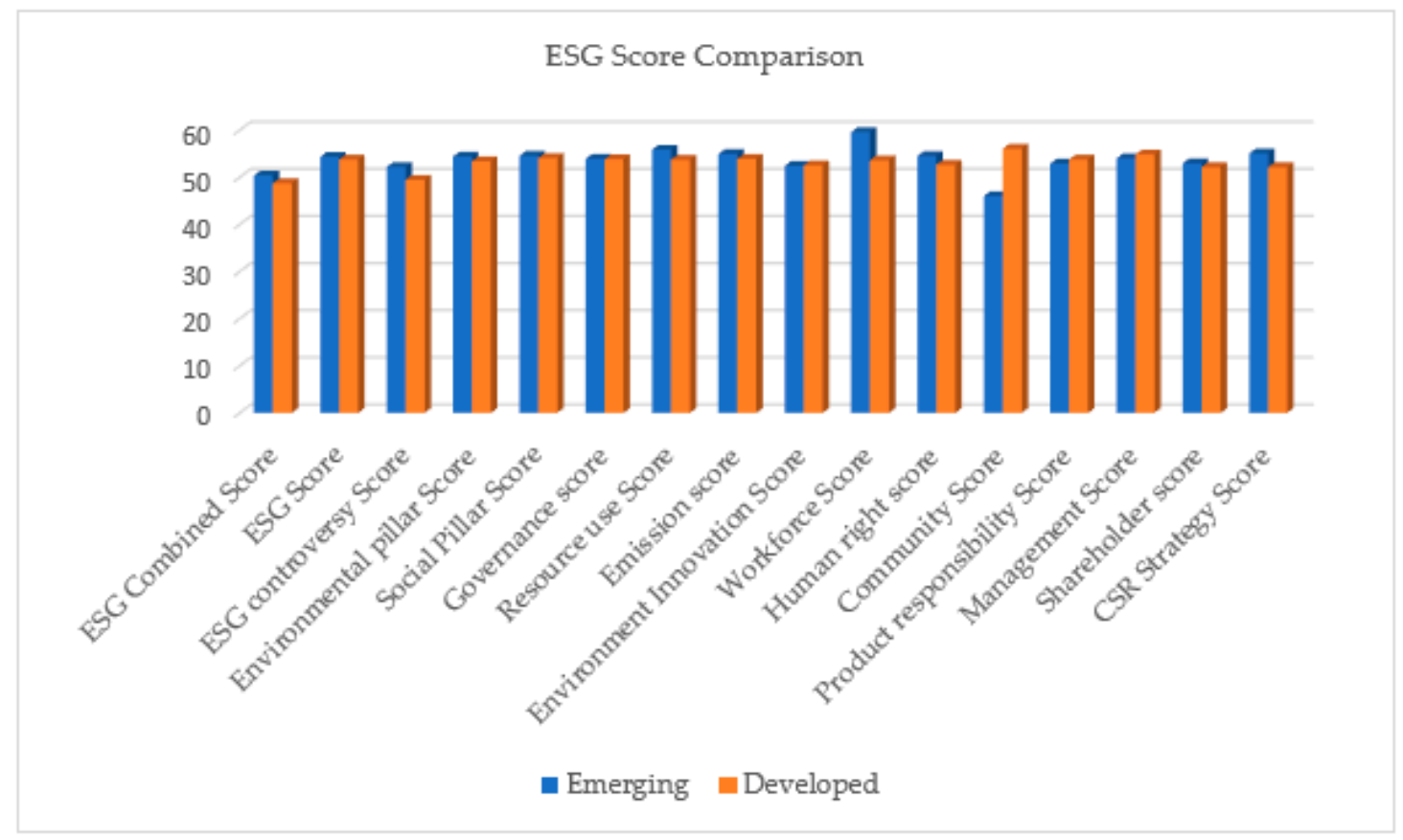

Figure 1. ESG score comparison: emerging vs. developed markets.

\subsection{Regression Analysis}

\subsubsection{ESG Composite Model and Corporate Financial Performance}

Table 6 demonstrates the regression results of the ESG Composite Model for the overall sample. In the first regression model, the financial performance variables of PE, Tobin $Q$ and ROE was regressed upon the social performance variable of ESG Combined score, which was discounted for significant 
ESG controversies. The Tobin Q and ROE model results indicated that stakeholder welfare initiatives may lead to significant improvements in valuation effects. The ESG Combined score was significantly and positively related to Tobin $\mathrm{Q}$ ( $\mathrm{t}$ statistics of 3.11 with significance at all levels) and ROE (t-statistics with significance at 5\% and 10\%). The result was consistent with [99]. Thus, ESG performance opportunities exist in numerous areas of the market. Similarly, [100] explained that environmental responsibility performance can positively influence the firms' $\mathrm{ROE}$ and ROA.

Table 6. Regression results of the ESG Composite Model for the overall sample.

\begin{tabular}{|c|c|c|c|c|c|c|}
\hline \multirow{2}{*}{ Variables } & \multicolumn{2}{|c|}{$\mathrm{P} / \mathrm{E}$} & \multicolumn{2}{|c|}{ Tobin Q } & \multicolumn{2}{|c|}{ ROE } \\
\hline & Coefficient & t-stat & Coefficient & t-stat & Coefficient & t-stat \\
\hline $\mathrm{C}$ & 68.82 & $2.95^{* * *}$ & 8.56 & $13.96^{* * *}$ & -46.30 & $-3.08^{* * *}$ \\
\hline ESG_COMSCORE & & & 0.01 & $3.11^{* * *}$ & 0.20 & $2.46^{* *}$ \\
\hline MGMT_EFF & -5.98 & $-2.37^{* *}$ & 0.68 & $10.19^{* * *}$ & 15.22 & $9.40^{* * *}$ \\
\hline DEBTA & & & & & 12.94 & $2.89^{* * *}$ \\
\hline DIVD & & & & & 1.18 & $3.35^{* * *}$ \\
\hline DEBT_EQUI & 0.00 & $3.05^{* * *}$ & 0.00 & $3.50 * * *$ & 0.00 & $-5.04^{* * *}$ \\
\hline BETA & & & -0.40 & $-5.43^{* * *}$ & & \\
\hline SG & 6.72 & $15.44^{* * *}$ & 0.13 & $11.10^{* * *}$ & 4.70 & $16.94^{* * *}$ \\
\hline SIZE_TA & -2.25 & $-2.22 * *$ & -0.34 & $-12.92 * * *$ & & \\
\hline AGE & & & 0.00 & $-1.86^{*}$ & & \\
\hline IND_BOARD & & & 0.01 & $3.88^{* * *}$ & 0.09 & $2.01 *$ \\
\hline SHARE_INVESTOR & 21.72 & $2.97^{* * *}$ & 0.60 & $3.14^{* * *}$ & 21.18 & $4.50^{* * *}$ \\
\hline R-squared & 0.387762 & & 0.382936 & & 0.336941 & \\
\hline Adjusted R-squared & 0.384751 & & 0.3799 & & 0.333631 & \\
\hline F-statistic & 128.7516 & & 126.1545 & & 101.8137 & \\
\hline Prob (F-statistic) & 0 & & 0 & & 0 & \\
\hline Durbin-Watson stat & 2.198061 & & 2.34 & & 2.218467 & \\
\hline Obs & 2861 & & 2861 & & 2820 & \\
\hline
\end{tabular}

Note: ${ }^{* * *},{ }^{* *}$ and ${ }^{*}$ indicate that the estimated coefficient is significantly different from zero at the 1 percent, 5 percent and 10 percent levels, respectively.

Moreover, the model results documented the positive relationship between social and financial performance, and the result was supported by [81]. Moreover, the result also reveals that the higher the management efficiency, the greater the valuation effects, based on Tobin Q and ROE model results. Evidence indicates that the higher the leverage, the higher the stock market and financial performance of firms. The ROE model results indicate that the higher the debt intensity proxied by debt to total assets (DEBTA), the higher the operating performance of firms. The leverage ratio of debt to equity was positively related to $\mathrm{P} / \mathrm{E}$ and Tobin $\mathrm{Q}$ with significance and negatively related to ROE with significance. The higher the risk, the lower the valuation effects (Tobin $Q$ Model results). The beta was negatively related to Tobin $Q$ with significance $(t=-5.43$ with significance at all levels). Sales growth (SG) was positively related to the valuation measures in all three models with significance at $1 \%, 5 \%$ and $10 \%$. The size of firms (proxied by log of total assets) was inversely related to the performance measure of $\mathrm{P} / \mathrm{E}$ and Tobin $\mathrm{Q}$. The age of firms was negatively related to the joint operating and stock market performance variable of Tobin Governance measures, which may also lead to value creation. The higher the percentage of independent directors in boards and ownership by investors, the greater the valuation effects, as measured by Tobin $Q$ and ROE models. The R\&D and Advt Intensity variables were dropped from the analyses because the sample size was truncated to a large extent.

\subsubsection{ESG Score, ESG Controversies and Corporate Financial Performance}

Table 7 reports the impacts of the ESG Score and ESG Controversies on valuation effects. In this model, the ESG Score and ESG Controversy scores were regressed upon the valuation measures of ROE, Tobin $\mathrm{Q}$ and P/E. The ESG Score was positively related to the valuation measure of ROE and Tobin $\mathrm{Q}$, and it was consistent with [101]. They explained that sustainability initiatives may lead to valuation 
enhancement. The ESG controversy score was negatively related to the stock market value measures of Tobin $\mathrm{Q}$ and $\mathrm{P} / \mathrm{E}$ ratios. Higher controversies generated by firms may lead to lower valuation effects for firms in the stock market. Markets are sceptical to the controversies generated by these firms. However, the result contradicted with [102] who highlighted that a high CSR may experience a high contemporaneous earnings-return relationship and great Tobin's $Q$. The impact of control variables on valuation measures were consistent with the ESG Composite Score model presented in Table 6.

Table 7. ESG Score and ESG Controversies impact on valuation effects.

\begin{tabular}{|c|c|c|c|c|c|c|}
\hline \multirow{2}{*}{ Variable } & \multicolumn{2}{|c|}{ ROE } & \multicolumn{2}{|c|}{ Tobin $Q$} & \multicolumn{2}{|c|}{$P / E$} \\
\hline & Coefficient & t-stat & Coefficient & t-stat & Coefficient & t-stat \\
\hline $\mathrm{C}$ & -41.748 & $-2.262 * *$ & 10.271 & $13.673^{* * *}$ & 77.218 & $2.691^{* * *}$ \\
\hline ESG_SCORE & 0.275 & $3.365^{* * *}$ & 0.018 & $5.443^{* * *}$ & 0.167 & 1.306 \\
\hline ESG_CONT & & & -0.007 & $-2.025 *$ & -0.005 & $-0.037^{* *}$ \\
\hline MGMT_EFF & 14.895 & $9.174^{* * *}$ & 0.643 & $9.696^{* * *}$ & -6.228 & $-2.460 * *$ \\
\hline DEBTA & 13.499 & $3.013^{* * *}$ & & & & \\
\hline DIVD & 1.181 & $3.343^{* * *}$ & -0.072 & $-5.208 * * *$ & & \\
\hline DEBT_EQUI & -0.005 & $-5.016^{* * *}$ & 0.000 & $3.572 * * *$ & 0.005 & $3.063^{* * *}$ \\
\hline BETA & & & -0.389 & $-5.366^{* * *}$ & & \\
\hline SG & 4.713 & $16.974^{* * *}$ & 0.129 & $11.298^{* * *}$ & 6.727 & $15.449^{* * *}$ \\
\hline SIZE_TA & & & -0.424 & $-13.797^{* * *}$ & -2.750 & $-2.343^{* *}$ \\
\hline AGE & & & -0.003 & $-2.297 * *$ & & \\
\hline IND_BOARD & & & 0.005 & $2.573^{* *}$ & & \\
\hline SHARE_INVESTOR & 22.130 & $4.688^{* * *}$ & 0.685 & $3.57^{* * *}$ & 22.364 & $3.050^{* * *}$ \\
\hline R-squared & 0.338202 & & 0.388998 & & 0.38797 & \\
\hline Adjusted R-squared & 0.334662 & & 0.385776 & & 0.384743 & \\
\hline Durbin-Watson stat & 2.220487 & & 2.363126 & & 2.19 & \\
\hline F-statistic & 95.52944 & & 120.7523 & & 120.231 & \\
\hline Prob (F-statistic) & 0 & & 0 & & 0 & \\
\hline
\end{tabular}

Note: ${ }^{* * *}, * *$ and ${ }^{*}$ indicate that the estimated coefficient is significantly different from zero at the 1 percent, 5 percent and 10 percent levels, respectively.

\subsubsection{ESG Pillar Scores and Corporate Financial Performance}

Table 8 shows the impact of pillar scores on the valuation measures. In this model, the impact of ESG pillars of environmental, governance and social initiatives on valuation measures were examined. The scores for environmental, governance and social initiatives were regressed upon the valuation measures and control variables. The higher the environmental initiatives, the greater the valuation effects, in terms of a high $\mathrm{P} / \mathrm{E}$. The environmental score was positively related to the $\mathrm{P} / \mathrm{E}$ ratio with significance $(t=1.766$ at $10 \%)$. This result could be explained because environmental initiatives can also facilitate firms to have a good accessibility to sources of funds in the capital market $[15,67,68]$.

The focus on social initiatives may also lead to value creation, as measured by Tobin Q. The social initiative scores of sample firms were positively related to Tobin $Q$ with significance at all levels. Governance performance may also result in high valuation effects, as proxied by Tobin $Q$ and ROE. Governance performance was directly related to ROE ( $\mathrm{t}$ statistics $=2.697$ with significance at all levels) and Tobin $Q$ (t value $=2.396$ with significance at $5 \%$ and $10 \%$ ). High management efficiency may lead to high valuation effects in terms of the ROE and Tobin Q model. Hence, corporate governance can provide a strong mechanism to improve the efficiency, equity returns and firm value [73].

The leverage measure of the total DEBTA was positively related to ROE, whilst the DOE ratio was significantly and negatively related to ROE. The Debt Equity ratio was positively related to the Tobin $\mathrm{Q}$ and $\mathrm{P} / \mathrm{E}$ ratio with significance. High dividend intensity positively and negatively affected ROE and Tobin $Q$, respectively, at significant levels. The higher the systematic risk, the lower the valuation effects in terms of Tobin $Q$. Sales growth positively and significantly impacted all valuation measures. The size of the firm was negatively related to the valuation measures of Tobin $\mathrm{Q}$ and $\mathrm{P} / \mathrm{E}$ with 
significance. The age of firms was negatively related to valuation effects. The higher the percentage of independent board members, the higher the valuation effects in terms of Tobin $Q$. The presence of ownership by investors was a positive determinant for value creation, as measured by all financial performance models [10].

Table 8. Impact of pillar scores on valuation measures.

\begin{tabular}{|c|c|c|c|c|c|c|}
\hline \multirow{2}{*}{ Variable } & \multicolumn{2}{|c|}{ ROE } & \multicolumn{2}{|c|}{ Tobin Q } & \multicolumn{2}{|c|}{$\mathrm{P} / \mathrm{E}$} \\
\hline & Coefficient & t-stat & Coefficient & t-stat & Coefficient & t-stat \\
\hline $\mathrm{C}$ & -44.455 & -2.372 & 10.102 & $13.218^{* * *}$ & 80.723 & $2.766^{* * * *}$ \\
\hline ENV & & & & & 0.190 & $1.766^{*}$ \\
\hline SOCIAL & & & 0.010 & $3.455^{* * *}$ & & \\
\hline GOVER & 0.157 & $2.697^{* * *}$ & 0.006 & $2.396^{* *}$ & & \\
\hline MGMT_EFF & 14.949 & $9.195^{* * *}$ & 0.644 & $9.704^{* * *}$ & -6.143 & $-2.422 * *$ \\
\hline DEBTA & 13.648 & $3.042 * * *$ & & & & \\
\hline DIVD & 1.174 & $3.312^{* * *}$ & -0.074 & $-5.309 * * *$ & & \\
\hline DEBT_EQUI & -0.005 & $-5.021^{* * *}$ & 0.000 & $3.582 * * *$ & 0.005 & $3.050 * * *$ \\
\hline BETA & & & -0.392 & $-5.397^{* * *}$ & & \\
\hline SG & 4.717 & $16.991^{* * *}$ & 0.129 & $11.299^{* * *}$ & 6.721 & $15.438^{* * *}$ \\
\hline SIZE_TA & & & -0.416 & $-13.277^{* * *}$ & -2.902 & $-2.425^{* *}$ \\
\hline AGE & & & -0.003 & $-2.223 * *$ & & \\
\hline IND_BOARD & & & 0.004 & $2.350 * *$ & & \\
\hline SHARE_INVESTOR & 22.378 & $4.743^{* * *}$ & 0.682 & $3.554^{* * *}$ & 22.456 & $3.064^{* * * *}$ \\
\hline R-squared & 0.339366 & & 0.389485 & & 0.388767 & \\
\hline Adjusted R-squared & 0.335357 & & 0.385834 & & 0.385112 & \\
\hline S.E. of regression & 50.63874 & & 2.09061 & & 79.82811 & \\
\hline Sum squared resid & 7185,119 & & $12,425.76$ & & $18,117,093$ & \\
\hline Log likelihood & $-15,060.08$ & & -6160.42 & & $-16,581.4$ & \\
\hline Durbin-Watson stat & 2.221131 & & 2.363016 & & 2.193374 & \\
\hline F-statistic & 84.66 & & 106.68 & & 106.3678 & \\
\hline Prob (F-statistic) & & & & & 0 & \\
\hline Obs & 2820 & & 2861 & & 2861 & \\
\hline
\end{tabular}

Note: ${ }^{* * *}, * *$ and ${ }^{*}$ indicate that the estimated coefficient is significantly different from zero at the 1 percent, 5 percent and 10 percent levels, respectively.

\subsubsection{ESG Component Scores of Different Pillars and Corporate Financial Performance}

The major components of the environmental pillar scores were resource use, emissions and innovation scores. The major components of social pillars were workforce score, human rights score, ESG community and product responsibility scores. The main components of the governance pillar scores were management, shareholder and CSR strategy scores. This study examined the impact of the component scores of various pillars on valuation measures. Table 9 reveals the regression results. In this model, the impact of the valuation measures on the category scores of all pillar scores were examined. The resource score was positively related to Tobin $\mathrm{Q}$ with significance $(\mathrm{t}=1.81$ with significance at all levels). This study documented that firms which reduced the use of materials, energy or water, or found eco-efficient sustainable solutions by improving supply chain management, were able to create high value in markets, as signified by the Tobin $Q$ ratio. Firms with an innovative strategy to reduce environmental costs and create new market opportunities through new environmental technologies or eco-designed products had high valuation effects [90]. The innovation score index was positively related to PE ratio with significance at all levels $(t=2.7)$. Innovation is one of the main determinants to develop the competitive advantage and the competitiveness of enterprises [90].

The workforce score was positively and significantly related to the valuation measures of ROE $(t=2.28)$ and Tobin $Q(t=3.9)$. This study documented that strategies which promoted the company's effectiveness towards job satisfaction, health and safe work place and development opportunities 
for workforce are create values for firms [65]. Such initiatives will lead to an improved operational performance, as measured by ROE and stock market performance and proxied by Tobin $Q$.

The ESG management score was positively related to ROE $(t=3.23)$ and Tobin $Q(t=4.08)$ with the significance at $1 \%$. The adoption of corporate governance principles was an important determinant of the valuation of firms. The focus on the best corporate governance practices by firms leads to an improved financial performance, as reflected by valuation measures such as ROE and Tobin $Q$ [73]. However, the ESG shareholder score (SHARE) was negatively related to Tobin Q measure with significance and the result contradicted with [103], indicating that the firms' propensity to use anti-takeover defence mechanisms will have lower valuation effects. Controlling shareholders may use his/her position in the firm to extract private benefits at the expense of the other shareholders.

Table 9. Impact of the component scores of various pillars on valuation measures.

\begin{tabular}{|c|c|c|c|c|c|c|}
\hline \multirow{2}{*}{ Variable } & \multicolumn{2}{|c|}{ ROE } & \multicolumn{2}{|c|}{ Tobin Q } & \multicolumn{2}{|c|}{$\mathrm{P} / \mathrm{E}$} \\
\hline & Coefficient & t-stat & Coefficient & t-stat & Coefficient & t-stat \\
\hline $\mathrm{C}$ & -43.5 & $-2.71 *$ & 9.173 & $13.71 *$ & 66.32 & $2.66 *$ \\
\hline RESOURCE & 0.04 & 0.62 & 0.005 & $1.81^{* * *}$ & 0.05 & 0.46 \\
\hline EMMI & 0.02 & 0.36 & 0.003 & 1.22 & -0.02 & -0.17 \\
\hline INNOV & 0.02 & 0.51 & -0.001 & -0.76 & 0.19 & $2.7 *$ \\
\hline WORK & 0.12 & $2.28 * *$ & 0.008 & $3.39 *$ & -0.07 & -0.82 \\
\hline HUMAN & 0.02 & 0.33 & -0.001 & -0.38 & 0.01 & 0.12 \\
\hline COMMU & 0.02 & 0.51 & 0.003 & 1.49 & 0.02 & 0.33 \\
\hline PRODUCT & -0.06 & -1.39 & 0.001 & 0.48 & -0.01 & -0.12 \\
\hline MGMT & 0.14 & $3.23 *$ & 0.007 & $4.08^{*}$ & 0.07 & 1.07 \\
\hline SHARE & -0.01 & -0.18 & -0.002 & $-1.43 *$ & 0.09 & 1.49 \\
\hline CSR & -0.04 & -0.84 & -0.007 & -3.53 & -0.07 & -0.96 \\
\hline MGMT_EFF & 14.53 & $9 *$ & 0.681 & $10.1^{*}$ & -6.49 & $-2.59 *$ \\
\hline DIVD & 1.01 & $2.85^{*}$ & -0.097 & $-6.91 *$ & -0.18 & -0.34 \\
\hline DEBT_EQUI & -0.004 & $-4.49 *$ & 0.0001 & $3.63 *$ & 0.004 & $3.22 *$ \\
\hline BETA & 0.5 & 0.28 & -0.241 & $-3.27^{*}$ & -3.8 & -1.38 \\
\hline SG & 4.8 & $17.37^{*}$ & 0.144 & 12.44 * & 6.65 & 15.39 * \\
\hline SIZE_TA & 0.5 & 0.67 & -0.366 & $-11.93 *$ & -2.44 & $-2.13 *$ \\
\hline AGE & -0.02 & -0.52 & -0.004 & $-2.34 *$ & 0 & -0.06 \\
\hline CAPEX & 9.14 & 0.39 & -1.357 & -1.39 & 48.3 & 1.33 \\
\hline IND_BOARD & 0.03 & 0.62 & 0.002 & 1.17 & -0.06 & -0.81 \\
\hline SHARE_STRAT & -5.13 & -1.15 & 0.167 & 0.9 & -6.2 & -0.9 \\
\hline SHARE_INVESTOR & 24.88 & $5.12 *$ & 0.655 & $3.25 *$ & 21.7 & $2.89 *$ \\
\hline R-squared & 0.336174 & & 0.359553 & & 0.390219 & \\
\hline Adjusted R-squared & 0.331192 & & 0.354816 & & 0.385708 & \\
\hline F-Stat & $67.47^{*}$ & & $75.89 *$ & & $86.51 *$ & \\
\hline Durbin-Watson stat & 2.200397 & & 2.312782 & & 2.190692 & \\
\hline
\end{tabular}

Note: ${ }^{* * *}, * *$ and ${ }^{*}$ indicate that the estimated coefficient is significantly different from zero at the 1 percent, 5 percent and 10 percent levels, respectively.

\subsection{Additional Test: Comparison of ESG Initiatives on Developed and Emerging Market Firms}

We examined if the ESG initiatives' impact on valuation differed among the firms from developed and emerging markets. A regression was conducted with the dummy variable of one for all developed market firms and zero for emerging market firms. Table 10 demonstrates the ESG initiatives' impact on the valuation effects. A variable of the product of the developed market dummy and corresponding ESG scores, pillars and categories were introduced in the analysis. All control variables were included in the analysis. Firstly, ESG, ESG Combined and ESG Controversy scores were regressed upon valuation measures, followed by the regression of the pillar scores and category scores on valuation measures. Table 10 shows the results for significant variables. The impact of the control variables on valuation measures were similar to the previous analysis with an overall sample. 
The valuation effects of ESG scores for developed market firms were positive and significant. The product of the dummy for the developed market firm and ESG Score had a coefficient of 0.014 with the significance at $5 \%$ and 10\% for the Tobin Q model. ESG initiatives received positive valuation effects for firms in developed markets. The controversies had significant negative valuation effects for developed market firms. On the basis of ROE and Tobin Q model results, the developed market firms had a significant positive relationship between environmental, social, governance scores and valuation measures. Results indicated that the developed market firms had higher valuation effects due to environmental, social and governance initiatives. In terms of environmental category scores, the emission and innovation scores' impact on the valuation measures were positive and significant. The dummy variable for the innovation score was significantly and positively related to the Tobin $Q$ Model. However, the PE model exhibited opposite results. The emission and innovation initiatives of the developed market firms had positive valuation effects.

The category work score was positively related to Tobin $Q$ for developed market firms with significance. The initiatives for the company's effectiveness towards job satisfaction and development opportunities for the workforce had higher valuation effects for developed market firms than emerging market firms. With respect to the implementation of the best corporate governance principles, the developed market firms had higher valuation effects.

Table 10. Comparison of impact of ESG initiatives on valuation effects.

\begin{tabular}{|c|c|c|c|c|c|c|}
\hline \multirow[b]{3}{*}{ Independent Variables } & \multicolumn{6}{|c|}{ Dependent Variables } \\
\hline & \multicolumn{2}{|l|}{ ROE } & \multicolumn{2}{|l|}{ Tobin Q } & \multicolumn{2}{|l|}{$\mathrm{P} / \mathrm{E}$} \\
\hline & Coefficient & t-stat & Coefficient & t-stat & Coefficient & t-stat \\
\hline $\mathrm{C}$ & 23.82 & 1.48 & 11.82 & $16.10^{* * *}$ & & \\
\hline DEV_DUMY & -14.51 & $-1.77 *$ & -0.98 & $-2.60^{* * *}$ & & \\
\hline \multirow[t]{3}{*}{ DEV_DUMY*ESG_SCORE } & 0.21 & 1.53 & 0.014 & $2.266^{* *}$ & & \\
\hline & \multicolumn{2}{|c|}{$\begin{array}{l}\text { Adjusted R-Squared = } \\
0.0559 ; \mathrm{F}=12.93\end{array}$} & \multicolumn{2}{|c|}{$\begin{array}{l}\text { Adjusted R-Squared = } \\
0.1481 ; \mathrm{F}=36.47\end{array}$} & & \\
\hline & Coefficient & t-stat & Coefficient & t-stat & Coefficient & t-stat \\
\hline $\mathrm{C}$ & 30.03 & 1.619 & 12.17 & $14.31^{* * *}$ & & \\
\hline DEV_DUMY & 12.12 & 1.60 & 0.60 & $1.72 *$ & & \\
\hline \multirow[t]{3}{*}{ DEV_DUMY*ESG_CONT } & -0.29 & $-2.07^{* *}$ & -0.015 & $-2.377^{* *}$ & & \\
\hline & \multicolumn{2}{|c|}{$\begin{array}{l}\text { Adjusted R-squared = } \\
0.0566 ; \mathrm{F}=13.07\end{array}$} & \multicolumn{2}{|c|}{$\begin{array}{l}\text { Adjusted R-squared = } \\
0.1472 ; \mathrm{F}=35.04\end{array}$} & & \\
\hline & Coefficient & t-stat & Coefficient & t-stat & & \\
\hline $\mathrm{C}$ & 11.89 & $16.38^{* * *}$ & & & & \\
\hline DEV_DUMY & -0.766 & $-2.658 * * *$ & & & & \\
\hline \multirow[t]{4}{*}{ DEV_DUMY*ENV } & 0.01 & $2.10 *$ & & & & \\
\hline & \multicolumn{2}{|c|}{$\begin{array}{l}\text { Adjusted R-squared = } \\
0.143 ; \mathrm{F}=35.10\end{array}$} & \multicolumn{2}{|c|}{$\begin{array}{l}\text { Adjusted R-squared = } \\
0.1472 ; \mathrm{F}=35.04\end{array}$} & & \\
\hline & \multicolumn{2}{|l|}{ ROE } & \multicolumn{2}{|l|}{ Tobin Q } & PE & \\
\hline & Coefficient & t-stat & Coefficient & t-stat & & \\
\hline $\mathrm{C}$ & & & 11.58 & $16.42^{* * *}$ & & \\
\hline DEV_DUMY & & & -0.68 & $-2.29 * *$ & & \\
\hline \multirow[t]{3}{*}{ DEV_DUMY*SOCIAL } & & & 0.0092 & $1.88^{*}$ & & \\
\hline & & & \multicolumn{2}{|c|}{$\begin{array}{l}\text { Adjusted R-squared = } \\
0.1472 ; \mathrm{F}=36.22\end{array}$} & & \\
\hline & Coefficient & t-stat & Coefficient & t-stat & & \\
\hline $\mathrm{C}$ & & & 12.07 & 0.799 & & \\
\hline DEV_DUMY & & & -13.46 & $-2.16^{* *}$ & & \\
\hline DEV_DUMY*GOVER & & & 0.207 & $1.93 *$ & & \\
\hline
\end{tabular}


Table 10. Cont.

\begin{tabular}{|c|c|c|c|c|c|c|}
\hline & \multicolumn{6}{|c|}{ Dependent Variables } \\
\hline & \multicolumn{2}{|l|}{ ROE } & \multicolumn{2}{|l|}{ Tobin Q } & \multicolumn{2}{|l|}{$\mathrm{P} / \mathrm{E}$} \\
\hline & & & \multicolumn{2}{|c|}{$\begin{array}{l}\text { Adjusted R-squared = } \\
0.054 ; \mathrm{F}=12.62\end{array}$} & & \\
\hline & Coefficient & t-stat & Coefficient & t-stat & & \\
\hline $\mathrm{C}$ & 20.55 & 1.33 & 11.75 & $16.62^{* * *}$ & & \\
\hline DEV_DUMY & -8.82 & $-1.75 *$ & -0.59 & $-2.53 * *$ & & \\
\hline \multirow{3}{*}{ DEV_DUMY*EMMI } & 0.1047 & 1.319 & 0.0069 & $1.889 *$ & & \\
\hline & \multicolumn{2}{|c|}{$\begin{array}{l}\text { Adjusted R-square = } \\
0.054 ; \mathrm{F}=12.55\end{array}$} & \multicolumn{2}{|c|}{$\begin{array}{l}\text { Adjusted R-squared = } \\
0.14 ; \mathrm{F}=35.11\end{array}$} & & \\
\hline & Coefficient & t-stat & Coefficient & t-stat & Coefficient & t-stat \\
\hline $\mathrm{C}$ & & & 10.88 & $16.06^{* * *}$ & 95.23 & $\begin{array}{l}3.80 \\
* * *\end{array}$ \\
\hline DEV_DUMY & & & -0.55 & $-2.48^{* *}$ & 7.026 & 0.851 \\
\hline \multirow[t]{3}{*}{ DEV_DUMY*INNOV } & & & 0.0069 & $1.89 *$ & -0.23 & $\begin{array}{l}-1.75 \\
*\end{array}$ \\
\hline & & & \multicolumn{2}{|c|}{$\begin{array}{l}\text { Adjusted R-squared = } \\
0.14 ; \mathrm{F}=33.50\end{array}$} & \multicolumn{2}{|c|}{$\begin{array}{l}\text { Adjusted R-squared = } \\
0.008 ; \mathrm{F}=2.68\end{array}$} \\
\hline & Coefficient & t-stat & Coefficient & t-stat & Coefficient & t-stat \\
\hline $\mathrm{C}$ & & & 11.087 & $16.34^{* * *}$ & & \\
\hline DEV_DUMY & & & -0.63 & $-2.44^{* *}$ & & \\
\hline \multirow[t]{3}{*}{ DEV_DUMY*WORK } & & & 0.0078 & $2.009 *$ & & \\
\hline & & & \multicolumn{2}{|c|}{$\begin{array}{l}\text { Adjusted R-squared = } \\
0.146 ; \mathrm{F}=35.88\end{array}$} & & \\
\hline & Coefficient & t-stat & Coefficient & t-stat & Coefficient & t-stat \\
\hline $\mathrm{C}$ & 6.80 & 0.46 & & & & \\
\hline DEV_DUMY & -9.93 & $-2.10 * *$ & & & & \\
\hline \multirow[t]{2}{*}{ DEV_DUMY*MGMT } & 0.14 & $1.846 *$ & & & & \\
\hline & \multicolumn{2}{|c|}{$\begin{array}{l}\text { Adjusted R-squared = } \\
0.055 ; \mathrm{F}=12.72\end{array}$} & & & & \\
\hline
\end{tabular}

Note: ${ }^{* * *},{ }^{* *}$ and ${ }^{*}$ indicate that the estimated coefficient is significantly different from zero at the 1 percent, 5 percent and 10 percent levels, respectively.

\section{Conclusions}

This study examined the impact of environmental, social and governance initiatives of 4886 firms on operational and market performance. The source of data was the Thomson Reuters database. The major focus of this study was to examine the distinctive characteristics of the ESG initiatives of firms in emerging and developed markets. Significant differences existed among developed and emerging markets, on account of the differences in social and managerial characteristics. Three models, which represents firm performance, were regressed upon the ESG scores, pillar scores and category scores, along with the control variables representing the financial and risk characteristics of the firms. A set of moderating variables representing the governance characteristics were included in the regression models.

The findings are as follows. Firstly, emerging market firms had higher ESG initiatives in terms of resource use, workforce, human rights and CSR strategies. By contrast, developed market firms had significantly higher community scores, which reflect the firm's initiatives for maintaining public health and upholding business ethics. Thus, maintaining these initiatives is important for value creation.

Secondly, in terms of ESG pillar scores, ESG initiatives may lead to significant improvements in valuation effects (Tobin $Q$ and $R O E$ ). Firms with higher environmental initiatives can improve 
shareholders' wealth $(\mathrm{P} / \mathrm{E})$. Social initiatives lead to value creation (Tobin $\mathrm{Q})$. Governance performance also results in high valuation (Tobin $Q$ and ROE).

Thirdly, from the ESG category scores' perspective, the firms which reduced the use of materials, energy or water, or find eco-efficient sustainable solutions by improving the supply chain management, created a high value (Tobin Q). Firms with an innovative strategy to reduce environmental costs and create new market opportunities through new environmental technologies or eco-designed products had high valuation effects. The workforce score was positively related to the valuation measures of ROE and Tobin Q. The ESG management score was positively and significantly related to ROE and Tobin $\mathrm{Q}$. The focus on the best corporate governance practices enhanced the financial performance of firms, whereas the ESG shareholder score was negatively related to Tobin $Q$. The firms' propensity to use anti-takeover defence mechanisms had low valuation effects.

Fourthly, when comparing between emerging and developed markets, the valuation effects of ESG scores for developed market firms were positive and significant. By contrast, the ROE and Tobin $\mathrm{Q}$ model results indicated that the developed market firms had a significant and positive relationship between environmental, social and governance scores, as well as between valuation measures. The emission and innovation initiatives in developed market firms had positive valuation effects. The category work score was positively related to Tobin $Q$.

The findings of this study have important implications for regulators and researchers. Firstly, this study documented the positive valuation effects for ESG initiatives adopted by firms. Managers must consider ESG as an investment, rather than an expense. Addressing the environmental, social and institutional requirements, as well as the different stakeholder requirements, results in value creation for firms. In this volatile corporate environment, the findings of the positive valuation effects of sustainability initiatives would be beneficial to investors and other stakeholder groups, such as regulators, policymakers and social stakeholders like community groups. The significance of the positive valuation effects of ESG initiatives indicated that ESG practices can be adopted as a part of the firm's business strategy.

The main strength of this study lies in its dataset and several sensitivity analyses in terms of model construction and alternative proxies, which confirmed the robustness of the results. However, this study could not explore the significance of the moderating variables, such as the R\&D intensity and advertisement intensity on ESG initiatives and firm performance due to the truncation of the sample size when we included these variables. Future researchers may assess the impact of the CSR initiatives on the firm performance of various developing countries in Asian and Latin American regions because the governance and social characteristics of these regions may vary.

Author Contributions: Conceptualisation, I.W.K.T and N.A.A.; methodology, R.K.B and S.K.S.; validation, R.K.B. and S.K.S.; formal analysis, I.W.K.T and N.A.A.; investigation, I.W.K.T. and N.A.A.; resources, R.K.B. and S.K.S.; writing—original draft preparation, R.K.B. and S.K.S.; writing-review and editing, I.W.K.T. and N.A.A. All authors have read and agreed to the published version of the manuscript.

Funding: This research is funded by the Foundation for Science and Technology Development of Ton Duc Thang University (FOSTECT), website: http://fostect.tdtu.edu.vn, under Grant FOSTECT.2017.BR.17.

Conflicts of Interest: The authors declare no conflict of interest.

\section{References}

1. Rodriguez-Fernandez, M. Social responsibility and financial performance: The role of good corporate governance. BRQ Bus. Res. Q. 2016, 19, 137-151. [CrossRef]

2. Zhao, C.; Guo, Y.; Yuan, J.; Wu, M.; Li, D.; Zhou, Y. ESG and Corporate Financial Performance: Empirical Evidence from China's Listed Power Generation Companies. Sustainability 2018, 10, 2607. [CrossRef]

3. Preston, L.E.; O’bannon, D.P. The corporate social-financial performance relationship: A typology and analysis. Bus. Soc. 1997, 36, 419-429. [CrossRef]

4. Barnett, M.L.; Salomon, R.M. Beyond dichotomy: The curvilinear relationship between social responsibility and financial performance. Strateg. Manag. J. 2006, 27, 1101-1122. [CrossRef] 
5. Vurro, C.; Perrini, F. Making the most of corporate social responsibility reporting: Disclosure structure and its impact on performance. Corp. Gov. Int. J. Bus. Soc. 2011, 11, 459-474.

6. Friedman, M. Capitalism and Freedom; University of Chicago press: Chicago, IL, USA, 1962.

7. Friedman, M. The Social Responsibility of Business is to Increase. In The New York Times Magazine; The New York Times Company: New York, NY, USA, 1970.

8. Sánchez, C. Value Shift: Why Companies Must Merge Social and Financial Imperatives to Achieve Superior Performance; Academy of Management Briarcliff Manor: Briarcliff Manor, NY, USA, 2003; p. 10510.

9. Okamoto, D. Sociality of Firms-The Relationship Among Profitability, Growth Potential, and Sociality in Terms of Corporate Appraisal; Nihon Keiei Gakkai: Tokyo, Japan, 2007; pp. 105-117.

10. Berman, S.L.; Wicks, A.C.; Kotha, S.; Jones, T.M. Does stakeholder orientation matter? The relationship between stakeholder management models and firm financial performance. Acad. Manag. J. 1999, 42, 488-506.

11. Freeman, R.E. Strategic management: A stakeholder theory. J. Manag. Stud. 1984, 39, 1-21.

12. Rowley, T.; Berman, S. A brand new brand of corporate social performance. Bus. Soc. 2000, 39, $397-418$. [CrossRef]

13. Mellahi, K.; Wood, G. The role and potential of stakeholders in "hollow participation": Conventional stakeholder theory and institutionalist alternatives. Bus. Soc. Rev. 2003, 108, 183-202. [CrossRef]

14. Ikram, A.; Li, Z.F.; Minor, D. CSR-contingent executive compensation contracts. J. Bank. Financ. 2019. [CrossRef]

15. Sharfman, M.P.; Fernando, C.S. Environmental risk management and the cost of capital. Strateg. Manag. J. 2008, 29, 569-592. [CrossRef]

16. Galbreath, J. ESG in focus: The Australian evidence. J. Bus. Ethics 2013, 118, 529-541. [CrossRef]

17. El Ghoul, S.; Guedhami, O.; Kwok, C.C.; Mishra, D.R. Does corporate social responsibility affect the cost of capital? J. Bank. Financ. 2011, 35, 2388-2406. [CrossRef]

18. Oh, C.H.; Park, J.-H.; Ghauri, P.N. Doing right, investing right: Socially responsible investing and shareholder activism in the financial sector. Bus. Horiz. 2013, 56, 703-714. [CrossRef]

19. Bassen, A.; Kovacs, A.M.M. Environmental, social and governance key performance indicators from a capital market perspective. Zeitschrift Für Wirtschafts-Und Unternehmensethik 2008, 9, 182-192. [CrossRef]

20. Cahan, S.F.; Chen, C.; Chen, L.; Nguyen, N.H. Corporate social responsibility and media coverage. J. Bank. Financ. 2015, 59, 409-422. [CrossRef]

21. Fatemi, A.; Fooladi, I.; Tehranian, H. Valuation effects of corporate social responsibility. J. Bank. Financ. 2015, 59, 182-192. [CrossRef]

22. Wang, Z.; Sarkis, J. Corporate social responsibility governance, outcomes, and financial performance. J. Clean. Prod. 2017, 162, 1607-1616. [CrossRef]

23. Benites, L.L.L.; Polo, E.F. A sustentabilidade como ferramenta estratégica empresarial: Governança corporativa e aplicação do Triple Bottom Line na Masisa. Revista de Administração da UFSM 2013, 6, 195-210. [CrossRef]

24. Gammeltoft, P.; Pradhan, J.P.; Goldstein, A. Emerging multinationals: home and host country determinants and outcomes. Int. J. Emerg. Mark. 2010, 5, 254-265. [CrossRef]

25. Horváthová, E. Does environmental performance affect financial performance? A meta-analysis. Ecol. Econ. 2010, 70, 52-59. [CrossRef]

26. Griesse, M.A. The geographic, political, and economic context for corporate social responsibility in Brazil. J. Bus. Ethics 2007, 73, 21-37. [CrossRef]

27. Khanna, T.; Palepu, K.G. Winning in Emerging Markets: A Road Map for Strategy and Execution; Harvard Business Press: Brighton, MA, USA, 2010.

28. Peng, M.W.; Wang, D.Y.; Jiang, Y. An institution-based view of international business strategy: A focus on emerging economies. J. Int. Bus. Stud. 2008, 39, 920-936. [CrossRef]

29. Bragdon, J.H.; Marlin, J. Is pollution profitable. Risk Manag. 1972, 19, 9-18.

30. Moskowitz, M. Choosing socially responsible stocks. Bus. Soc. Rev. 1972, 1, 71-75.

31. Margolis, J.D.; Elfenbein, H.A.; Walsh, J.P. Does it pay to be good? A meta-analysis and redirection of research on the relationship between corporate social and financial performance. Ann. Arbor. 2007, 1001, 48109-1234.

32. Griffin, J.J.; Mahon, J.F. The corporate social performance and corporate financial performance debate: Twenty-five years of incomparable research. Bus. Soc. 1997, 36, 5-31. [CrossRef] 
33. Pava, M.L.; Krausz, J. The association between corporate social-responsibility and financial performance: The paradox of social cost. J. Bus. Ethics 1996, 15, 321-357. [CrossRef]

34. Roman, R.M.; Hayibor, S.; Agle, B.R. The relationship between social and financial performance: Repainting a portrait. Bus. Soc. 1999, 38, 109-125. [CrossRef]

35. Margolis, J.D.; Walsh, J.P. Misery loves companies: Rethinking social initiatives by business. Adm. Sci. Q. 2003, 48, 268-305. [CrossRef]

36. Orlitzky, M.; Schmidt, F.L.; Rynes, S.L. Corporate social and financial performance: A meta-analysis. Organization studies. 2003, 24, 403-441. [CrossRef]

37. Carroll, A.B.; Shabana, K.M. The business case for corporate social responsibility: A review of concepts, research and practice. Int. J. Manag. Rev. 2010, 12, 85-105. [CrossRef]

38. Carroll, A.B. Corporate social responsibility: Evolution of a definitional construct. Bus. Soc. 1999, 38, $268-295$. [CrossRef]

39. Gond, J.-P.; Crane, A. Corporate social performance disoriented: Saving the lost paradigm? Bus. Soc. 2010, 49, 677-703. [CrossRef]

40. Al-Tuwaijri, S.A.; Christensen, T.E.; Hughes Ii, K. The relations among environmental disclosure, environmental performance, and economic performance: A simultaneous equations approach. Account. Organ. Soc. 2004, 29, 447-471. [CrossRef]

41. Becchetti, L.; Di Giacomo, S.; Pinnacchio, D. Corporate social responsibility and corporate performance: Evidence from a panel of US listed companies. Appl. Econ. 2008, 40, 541-567. [CrossRef]

42. Ullmann, A.A. Data in search of a theory: A critical examination of the relationships among social performance, social disclosure, and economic performance of US firms. Acad. Manag. Rev. 1985, 10, 540-557.

43. Cochran, P.L.; Wood, R.A. Corporate social responsibility and financial performance. Acad. Manag. J. 1984, $27,42-56$.

44. McWilliams, A.; Siegel, D. Corporate social responsibility and financial performance: Correlation or misspecification? Strateg. Manag. J. 2000, 21, 603-609. [CrossRef]

45. McGuire, J.B.; Sundgren, A.; Schneeweis, T. Corporate social responsibility and firm financial performance. Acad. Manag. J. 1988, 31, 854-872.

46. Waddock, S.A.; Graves, S.B. The corporate social performance-financial performance link. Strateg. Manag. J. 1997, 18, 303-319. [CrossRef]

47. Peterson, R.T.; Hermans, C.M. The communication of social responsibility by US banks. Int. J. Bank Mark. 2004, 22, 199-211. [CrossRef]

48. Porter, M. LINDEV Green and Competitive. Harv. Bus. Rev. 1995, 73, 120-134.

49. Reinhardt, F.L. Bringing the environment down to earth. Harv. Bus. Rev. 1999, 77, 149-157. [PubMed]

50. Singh, J. Making business sense of environmental compliance. MIT Sloan Manag. Rev. 2000, 41, 91.

51. Bhattacharya, C.B.; Sen, S. Doing better at doing good: When, why, and how consumers respond to corporate social initiatives. Calif. Manag. Rev. 2004, 47, 9-24. [CrossRef]

52. Callan, S.J.; Thomas, J.M. Corporate financial performance and corporate social performance: An update and reinvestigation. Corp. Soc. Responsib. Environ. Manag. 2009, 16, 61-78. [CrossRef]

53. Zhao, X.; Murrell, A.J. Revisiting the corporate social performance-financial performance link: A replication of $\mathrm{W}$ addock and G raves. Strateg. Manag. J. 2016, 37, 2378-2388. [CrossRef]

54. Busch, T.; Friede, G. The robustness of the corporate social and financial performance relation: A second-order meta-analysis. Corp. Soc. Responsib. Environ. Manag. 2018, 25, 583-608. [CrossRef]

55. Shin, J.-Y.; Moon, J.J.; Kang, J. How Do National Institutions Moderate the Relationship between CSP and CFP? Acad. Manag. Proc. 2015, 2015, 10995. [CrossRef]

56. Okamoto, D. Social relationship of a firm and the CSP-CFP relationship in Japan: Using artificial neural networks. J. Bus. Ethics 2009, 87, 117-132. [CrossRef]

57. Wood, D.J. Measuring corporate social performance: A review. Int. J. Manag. Rev. 2010, 12, 50-84. [CrossRef]

58. Marom, I.Y. Toward a unified theory of the CSP-CFP link. J. Bus. Ethics 2006, 67, 191-200. [CrossRef]

59. Barnett, M.L. Stakeholder influence capacity and the variability of financial returns to corporate social responsibility. Acad. Manag. Rev. 2007, 32, 794-816. [CrossRef]

60. Scherer, A.G.; Palazzo, G. The new political role of business in a globalized world: A review of a new perspective on CSR and its implications for the firm, governance, and democracy. J. Manag. Stud. 2011, 48, 899-931. [CrossRef] 
61. KPMG. International Survey of Corporate Responsibility Reporting; KPMG: Amstelveen, The Netherlands, 2008.

62. Peloza, J. The challenge of measuring financial impacts from investments in corporate social performance. J. Manag. 2009, 35, 1518-1541. [CrossRef]

63. Surroca, J.; Tribó, J.A.; Waddock, S. Corporate responsibility and financial performance: The role of intangible resources. Strateg. Manag. J. 2010, 31, 463-490. [CrossRef]

64. Rivoli, P.; Waddock, S. The Grand Misapprehension a Response to Aneel Karnani's “Doing Well by Doing Good': The Grand Illusion". Calif. Manag. Rev. 2011, 53, 112-116. [CrossRef]

65. Hoffman, A.J. Competitive Environmental Strategy: A Guide to the Changing Business Landscape; Island Press: Washington, DC, USA, 2000.

66. Wagner, M. The role of corporate sustainability performance for economic performance: A firm-level analysis of moderation effects. Ecol. Econ. 2010, 69, 1553-1560. [CrossRef]

67. King, A.A.; Lenox, M.J. Does it really pay to be green? An empirical study of firm environmental and financial performance: An empirical study of firm environmental and financial performance. J. Ind. Ecol. 2001, 5, 105-116. [CrossRef]

68. Bauer, R.; Derwall, J.; Otten, R. The ethical mutual fund performance debate: New evidence from Canada. J. Bus. Ethics 2007, 70, 111-124. [CrossRef]

69. Hart, S.L.; Ahuja, G. Does it pay to be green? An empirical examination of the relationship between emission reduction and firm performance. Bus. Strategy Environ. 1996, 5, 30-37. [CrossRef]

70. Russo, M.V.; Fouts, P.A. A resource-based perspective on corporate environmental performance and profitability. Acad. Manag. J. 1997, 40, 534-559.

71. Stefan, A.; Paul, L. Does it pay to be green? A systematic overview. Acad. Manag. Perspect. 2008, 22 , 45-62. [CrossRef]

72. Artiach, T.; Lee, D.; Nelson, D.; Walker, J. The determinants of corporate sustainability performance. Account. Financ. 2010, 50, 31-51.

73. Giroud, X.; Mueller, H.M. Corporate governance, product market competition, and equity prices. J. Financ. 2011, 66, 563-600. [CrossRef]

74. Li, Z.F. Mutual monitoring and corporate governance. J. Bank. Financ. 2014, 45, 255-269.

75. Black, B.; Kim, W. The effect of board structure on firm value: A multiple identification strategies approach using Korean data. J. Financ. Econ. 2012, 104, 203-226. [CrossRef]

76. Chung, K.H.; Zhang, H. Corporate governance and institutional ownership. J. Financ. Quant. Anal. 2011, 46, 247-273. [CrossRef]

77. Bhagat, S.; Bolton, B. Director ownership, governance, and performance. J. Financ. Quant. Anal. 2013, 48, 105-135. [CrossRef]

78. Greening, D.W.; Turban, D.B. Corporate social performance as a competitive advantage in attracting a quality workforce. Bus. Soc. 2000, 39, 254-280. [CrossRef]

79. Hong, B.; Li, Z.; Minor, D. Corporate governance and executive compensation for corporate social responsibility. J. Bus. Ethics 2016, 136, 199-213. [CrossRef]

80. Li, Z.; Minor, D.B.; Wang, J.; Yu, C. A learning curve of the market: Chasing alpha of socially responsible firms. J. Econ. Dyn. Control. 2019, 109, 103772. [CrossRef]

81. Gallardo-Vázquez, D.; Valdez-Juárez, L.E.; Castuera-Díaz, Á.M. Corporate Social Responsibility as an Antecedent of Innovation, Reputation, Performance, and Competitive Success: A Multiple Mediation Analysis. Sustainability 2019, 11, 5614. [CrossRef]

82. Campbell-Verduyn, M. Merely TINCering around: The shifting private authority of technology, information and news corporations. Bus. Politics 2016, 18, 143-170. [CrossRef]

83. Van Duuren, E.; Plantinga, A.; Scholtens, B. ESG integration and the investment management process: Fundamental investing reinvented. J. Bus. Ethics 2016, 138, 525-533. [CrossRef]

84. Gallego-Álvarez, I.; Quina-Custodio, I.A. Corporate social responsibility reporting and varieties of capitalism: An international analysis of state-led and liberal market economies. Corp. Soc. Responsib. Environ. Manag. 2017, 24, 478-495. [CrossRef]

85. Smirlock, M.; Gilligan, T.; Marshall, W. Tobin's q and the Structure-Performance Relationship. Am. Econ. Rev. 1984, 74, 1051-1060.

86. Kumbirai, M.; Webb, R. A financial ratio analysis of commercial bank performance in South Africa. Afr. Rev. Econ. Financ. 2010, 2, 30-53. 
87. Kothari, S.P.; Sloan, R.G. Information in prices about future earnings: Implications for earnings response coefficients. J. Account. Econ. 1992, 15, 143-171. [CrossRef]

88. Cohen, D.; Mashruwala, R.; Zach, T. The use of advertising activities to meet earnings benchmarks: Evidence from monthly data. Rev. Account. Stud. 2010, 15, 808-832. [CrossRef]

89. Ting, I.W.K.; Lean, H.H. Capital structure of government-linked companies in malaysia. Asian Acad. Manag. J. Account. Financ. 2011, 7, 137-156.

90. Morbey, G.K. R\&D expenditures and profit growth. Res. Technol. Manag. 1989, 32, $20-23$.

91. Pettengill, G.N.; Sundaram, S.; Mathur, I. The conditional relation between beta and returns. J. Financ. Quant. Anal. 1995, 30, 101-116. [CrossRef]

92. Pástor, L'.; Pietro, V. Stock valuation and learning about profitability. J. Financ. 2003, 58, 1749-1789. [CrossRef]

93. Chang, C.; Lee, A.C.; Lee, C.F. Determinants of capital structure choice: A structural equation modeling approach. Q. Rev. Econ. Financ. 2009, 49, 197-213. [CrossRef]

94. Bhandari, L.C. Debt/equity ratio and expected common stock returns: Empirical evidence. J. Financ. 1988, 43, 507-528. [CrossRef]

95. Ting, I.W.-K.; Kweh, Q.-L.; Chan, Y.-C. Does organizational growth contribute to profitability? Evidence from Malaysian public listed companies. Int. J. Bus. Soc. 2014, 15, 267.

96. Black, F.; Scholes, M. The effects of dividend yield and dividend policy on common stock prices and returns. J. Financ. Econ. 1974, 1, 1-22. [CrossRef]

97. Lau, S.T.; Lee, C.T.; McInish, T.H. Stock returns and beta, firms size, E/P, CF/P, book-to-market, and sales growth: Evidence from Singapore and Malaysia. J. Multinatl. Financ. Manag. 2002, 12, 207-222. [CrossRef]

98. Hotchkiss, E.S. Postbankruptcy performance and management turnover. J. Financ. 1995, 50, 3-21. [CrossRef]

99. Friede, G.; Busch, T.; Bassen, A. ESG and financial performance: Aggregated evidence from more than 2000 empirical studies. J. Sustain. Financ. Invest. 2015, 5, 210-233. [CrossRef]

100. Lee, K.H.; Cin, B.C.; Lee, E.Y. Environmental responsibility and firm performance: The application of an environmental, social and governance model. Bus. Strategy Environ. 2016, 25, 40-53. [CrossRef]

101. Kim, M.; Kim, Y. Corporate social responsibility and shareholder value of restaurant firms. Int. J. Hosp. Manag. 2014, 40, 120-129. [CrossRef]

102. Gao, L.; Zhang, J.H. Firms' earnings smoothing, corporate social responsibility, and valuation. J. Corp. Financ. 2015, 32, 108-127. [CrossRef]

103. Perrini, F.; Rossi, G.; Rovetta, B. Does ownership structure affect performance? Evidence from the Italian market. Corp. Gov. Int. Rev. 2008, 16, 312-325. [CrossRef] 